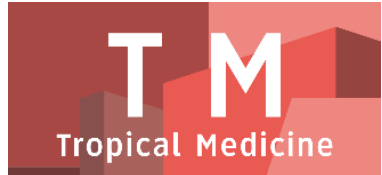

PAPER - OPEN ACCESS

\title{
Pengaruh Ramuan Jamu Antihiperkolesterolemia Terhadap Kadar Asam Urat Pasien Dengan Hiperkolesterol Ringan
}

\author{
Author : Zuraida Zulkarnain \\ DOI $\quad: 10.32734 /$ tm.v1i3.285 \\ Electronic ISSN : 2623-0542 \\ Print ISSN : 2623-0550
}

Volume 1 Issue 3 - 2018 TALENTA Conference Series: Tropical Medicine (TM)

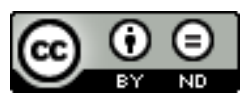

This work is licensed under a Creative Commons Attribution-NoDerivatives 4.0 International License.

Published under licence by TALENTA Publisher, Universitas Sumatera Utara
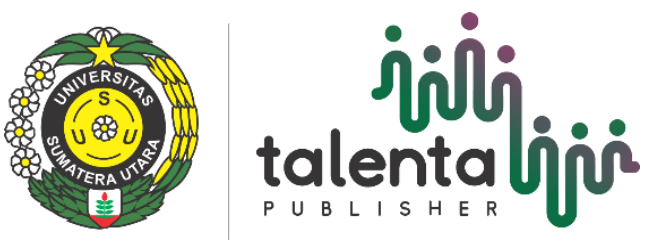


\title{
Pengaruh Ramuan Jamu Antihiperkolesterolemia Terhadap Kadar Asam Urat Pasien Dengan Hiperkolesterol Ringan
}

\author{
Zuraida Zulkarnain ${ }^{\mathrm{a}^{*}}$, Ulfa Fitriani ${ }^{\mathrm{b}}$, Enggar Wijayanti ${ }^{\mathrm{c}}$, Ulfatun Nisa ${ }^{\mathrm{d}}$ \\ ${ }^{a b c d}$ Balai Besar Penelitian dan Pengembangan Tanaman Obat dan Obat Tradisional \\ Jalan Lawu no 11, Tawangmangu, Karanganyar, Jawa Tengah \\ zuraida.zu@gmail.com
}

\begin{abstract}
Abstrak
Ramuan jamu antihiperkolesterolemia terdiri dari daun jati cina, daun jati belanda, daun teh hijau, tempuyung, rimpang temulawak, rimpang kunyit dan herba meniran. Daun jati belanda dan daun teh hijau memiliki kandungan purin dalam bentuk kafein dan teobromin yang berpotensi menyebabkan peningkatan asam urat. Penelitian ini bertujuan untuk mengetahui kadar asam urat serum darah pasien yang meminum ramuan jamu antihiperkolesterolemia. Penelitian ini merupakan observasi klinik dengan jumlah subyek 50 orang di Rumah Riset Jamu (RRJ) Hortus Medicus pada tahun 2014. Subjek merupakan pasien dengan diagnosis hiperkolesterolemia ringan (kadar kolesterol serum 200-240 mg/dl) yang diterapi dengan ramuan jamu antihiperkolesterolemia selama 28 hari. Parameter yang dinilai adalah kadar asam urat serum pada awal (H-0) dan akhir obeservasi (H-28). Data diolah dengan uji t berpasangan menggunakan bantuan program SPSS. Hasil terjadi peningkatan rata-rata kadar asam urat dari 5,31 $\pm 1,17$ $\mathrm{mg} / \mathrm{dl}$ menjadi $5,47 \pm 1,29 \mathrm{mg} / \mathrm{dl}$. Peningkatan masih dalam rentang nilai normal. Pada uji t berpasangan diperoleh nilai $\mathrm{p}=0,384$ yang berarti tidak ada perbedaan rerata kadar asam urat sebelum dan sesudah minum jamu. Kesimpulan terdapat peningkatan ringan rerata kadar asam urat serum pasien yang secara statistik tidak bermakna dan masih berada dalam rentang nilai normal setelah pemberian ramuan jamu antihiperkolesterolemia selama 28 hari.
\end{abstract}

Kata kunci: asam urat, jamu antihiperkolesterolemia, jati belanda, teh hijau

\begin{abstract}
Antihipercholesterolemia Jamu formula consists of Cassia senna leaves, Guazuma ulmifolia leaves, Camellia sinensis leaves, Sonchus arvensis, Curcuma xanthorrhiza rhizomes, Curcuma longa rhizomes and Phyllanthus niruri. Caffeine and Theobromine contained in Guazuma ulmifolia and Camellia sinensis leaves have the potential to increased serum uric acid. This study aim to determine the level of serum uric acid blood of patients who take antihiperkolesterolemia Jamu formula.This study was a clinical observation with a total of 50 subjects conducted at Rumah Riset Jamu (RRJ) Hortus Medicus in 2014. Subjects were patients with a diagnosis of mild hypercholesterolaemia (serum cholesterol level $200-240 \mathrm{mg} / \mathrm{dl}$ ) treated with herbs antihipercholesterolemia during 28 days. Parameters assessed were serum uric acid levels at baseline (H-0) and end of observation (H-28). Data were analyse using paired $\mathrm{t}$ test with the help of SPSS program. The results showed the uric acid mean level was increase from $5.31+1.17 \mathrm{mg} /$ $\mathrm{dl}$ to $5.47+1.29 \mathrm{mg} / \mathrm{dl}$ at days 28 . However it was still within the normal range. Paired $\mathrm{t}$ test obtained $\mathrm{p}$ value $=0.384$ which means there was no difference of uric acid mean level before and after study. There was a slight increase in mean serum uric acid levels that statistic ally insignificant and remained within normal range after administration antihi percholesterolemia jamu formula for 28 days.
\end{abstract}

Keywords : uric acid, antihipercholesterolemia Jamu, Guazuma ulmifolia, Camelllia sinensis 


\section{Pendahuluan}

Saat ini penelitian dan pengembangan obat dari bahan alam sedang mengalami trend meningka[1]. Di Indonesia, penelitian tentang khasiat dan keamanan jamu mengikuti alur uji klinik mulai dari uji senyawa aktif, uji pra klinik dan uji klinik. Jamu atau obat herbal selama ini dianggap lebih aman dibandingkan obat kimia. Akan tetapi masih sedikit bukti ilmiah yang menjelaskan tentang aspek keamanan jamu[2].

Hiperkolesterolemia merupakan faktor risiko terjadinya penyakit kardiovaskuler sehingga harus ditangani dengan baik. Ramuan jamu antihiperkolesterolemia yang terdiri dari daun jati cina, daun jati belanda, daun teh hijau, tempuyung, rimpang temulawak, rimpang kunyit dan herba meniran dapat membantu pasien untuk menurunkan kolesterol dalam darahnya. Khasiat masing-masing tanaman penyusun jamu dalam bentuk sediaan tunggal maupun sebagai ramuan dalam menurunkan kolesterol telah dibuktikan secara ilmiah[3].

Hiperurisemia adalah suatu kondisi dimana kadar asam urat dalam serum darah melebihi nilai normal[4]. Peningkatan kadar asamurat dalam darah dapat terjadi karena faktor genetik yang mempengaruhi metabolisme asam urat dan ekskresinya, produksi yang berlebihan seperti pada intake makanan tinggi purin, maupun ekskresi yang rendah karena penyakit ginjal[5]. Hiperurisemia dapat memicu terjadinya disfungsi endotel akibatpenghambatan produksi nitric oxide sehingga meningkatkan kejadian hipertensi, penyakit kardiovaskuler dan ginjal kronis[6]. Selain itu hiperurisemia merupakan perkusor terjadinya artritis gout[4].

Daun teh hijau dan jati belanda memiliki kandungan purin dalam bentuk kafein dan teobromin[7,8]. Kafein dan teobromin merupakan golonganmethyl xanthineyang di dalam tubuh manusia akan dikatabolisme menjadi asam urat sehingga berpotensi menimbulkan hiperurisemia[9,10]. Penelitian ini bertujuan untuk mengetahui kadar asam urat serum darah pasien hiperkolesterolemia ringan yang diterapi dengan ramuan jamu antihiperkolesterolemia selama 28 hari.

\section{Bahan dan Metode}

Ramuan jamu antihiperkolesterolemia dengan dosis harian sebagai berikut : 6 gram daun jati belanda (Guazuma ulmifolia L), 1 gram daun jati cina (Cassia sennae L), 6 gram tempuyung (Sonchus arvensis), 5 gram daun teh hijau (Camellia sinensis L) , 5 gram temulawak (C. xanthorrhiza), 4 gram kunyit (C. longa), 3 gram meniran (Philanthus niruri). Ramuan jamu disiapkan dalam bentuk simplisia di RRJ Hortus medicus dan diberikan kepada pasien untuk direbus di rumah dengan 4 gelas air selama kurang lebih 15 menit sampai air menjadi kira-kira 2 gelas, diminum pagi 1 gelas sore 1 gelas.Pemberian jamu selama 28 hari.

Pasien yang direkrut dalam penelitian ini adalah pasien dengan hiperkolesterolemia ringan (kadar kolesterol dalam plasma $<240 \mathrm{mg} / \mathrm{dl}$ ) berjumlah 50 subjek. Pasien tidak memiliki penyakit berat dan tidak alergi terhadap komponen jamu. Subjek dianjurkan untuk menghindari makanan tinggi lemak, berolah raga ringan secara teratur dan cukup minum air putih. Penelitian dilakukan pada tahun 2014.

Kadar asam urat diukur pada hari ke -0 (H-0) sebelum minum jamu dan hari ke -28 (H-28) setelah minum jamu bersamaan dengan pemeriksaan kadar kolesterol. Darah pasien diambil sebanyak 3 cc pada vena cubiti lalu dimasukkan ke dalam tabung vacuum. Darah disentrifuge dan serum diambil, kemudian dimasukkan ke dalam alat kimia analizer merek URIT. Pemeriksaan asam urat membutuhkan waktu sekitar 10-15 menit, hasil pemeriksaan dapat langsung dibaca pada layar monitor komputer yang terhubung dengan alat. Nilai normal asam urat sebagai acuan dalam penelitian ini untuk perempuan 2,6-6,0 mg/dl dan untuk laki-laki 3,5-7,2 mg/dl[11].

\subsection{Analisi Data}

Data yang diperoleh akan dilakukan uji normalitas Shapiro-Wilk karena jumlah data kecil $(<50)$. Apabila distribusi data normal akan dilanjutkan dengan uji t berpasangan dan apabila tidak normal akan dianalisis dengan uji Wilcoxon untuk membandingkan antara data sebelum dan sesudah observasi. 


\section{Hasil dan Pembahasan}

Sebanyak 50 pasien mengikuti penelitian sampai selesai. Subjek laki-laki berjumlah 17 pasien dan perempuan 33 pasien.Rerata umur subjek 47 tahun. Hiperkolesterolemiamerupakan penyakit degeneratif yang meningkat seiring bertambahnya usia[12]. Hasil uji normalitas Shapiro-Wilk pada kelompok data kadar asam urat berdasar jenis kelamin dan seluruh data sebelum maupun sesudah observasi menunjukkan nilai signifikan yaitup $>0,05$ sehingga analisa dilanjutkan dengan uji t berpasangan (Tabel 1).

Tabel 1. Hasil Uji Shapiro - Wilk

\begin{tabular}{lll}
\hline Kelompok Data & Jumlah subjek (N) & P \\
\hline Kadar asam urat pada subyek laki-laki H-0 & 17 & 0,304 \\
Kadar asam urat pada subyek laki-laki H-28 & 17 & 0,873 \\
Kadar asam urat pada subyek perempuan H-0 & 33 & 0,588 \\
Kadar asam urat pada subyek perempuan H-28 & 33 & 0,635 \\
Kadar asam urat pada semua subyek H-0 & 50 & 0,337 \\
Kadar asam urat pada semua subyek H-28 & 50 & 0,220 \\
\hline
\end{tabular}

*nilai signifikan pada taraf kepercayaan $95 \%$

Rerata kadar asam urat serum subjek laki-laki, perempuan dan gabungan keduanya pada akhir observasi (H-28) mengalami sedikit peningkatan dibandingkan awal (H-0). Peningkatan tersebut masih berada dalam rentang nilai normal. Hasil uji t berpasangan menunjukkan tidak ada perbedaan rerata kadar asam urat sebelum dan sesudah observasi pada kelompok subjek laki-laki, perempuan dan keduanya (Tabel 2).

Ramuan jamu antihiperkolesterolemia tersusun diantaranya oleh daun jati belanda dan daun teh hijau yang memiliki kandungan purin dalam bentuk teobromin dan kafein(8,7). Dalam 1 gram teh hijau yang diseduh dengan $18 \mathrm{ml}$ air mendidih dan dibiarkan selama 3 menit mengandung $57 \pm 0,1 \mathrm{mg} \mathrm{L}^{-1}$ kafein, $866 \pm 16 \mathrm{mg} \mathrm{L}^{-1}$ teobromin[7]. Berdasarkan kajian sistematik yang dilakukan Zang et alpada tahun 2017 ada 3 penelitian yang membuktikan bahwa konsumsi teh hijau berkaitan dengan peningkatan kadar asam urat serum, namun tidak berkaitan dengan terjadinya hiperurisemia maupun artritis gout[4].

Tabel 2. Rerata Kadar Asam Urat

\begin{tabular}{llllll}
\hline Kelompok & H-0 & & H-28 & \multicolumn{2}{c}{ S } \\
\cline { 2 - 5 } & Rerata & SD & Rerata & 1,09 & $0,646^{*}$ \\
\hline Laki-laki & 6,10 & 1,02 & 6,16 & 1,24 & $0,393^{*}$ \\
Perempuan & 4,88 & 1,01 & 5,07 & 1,29 & $0,384^{*}$ \\
Semua subjek & 5,31 & 1,17 & 5,47 & & 1,29 \\
\hline
\end{tabular}

*uji t berpasangan pada tingkat kepercayaan $95 \%$

Tabel 3. Perubahan Kadar asam urat H-28 dibanding H-0

\begin{tabular}{llll}
\hline Jenis kelamin & Naik & Turun & Tetap \\
\hline Laki-laki & 10 & 6 & 1 \\
Perempuan & 16 & 17 & 0 \\
\hline
\end{tabular}

Analisa pada masing-masing subjek setelah pemberian jamu selama 28 hari, didapatkan 26 subjek mengalami kenaikan kadar asam urat, 23 subjek mengalami penurunan kadar asam urat dan 1 subjek kadarasam uratnya tidak berubah (Tabel 3). Sebanyak 7 subjek yaitu 2 laki-laki dan 5 perempuan mengalami peningkatan kadar asam urat melebihi nilai normal (hiperurisemia). Duasubjek perempuan yang mengalami penurunan kadar asam urat ternyata masih memiliki nilai asam urat di atas normal (hiperurisemia). Hal ini terjadi karena beberapa subjek telah menderita hiperurisemia asimtomatik pada awal observasi (Tabel 4). Kadar asam urat tertinggi diakhir observasi pada laki-laki 
$7,9 \mathrm{mg} / \mathrm{dl}$ dan perempuan 7,6 mg/dl, sedangkan peningkatan asam urat tertinggi adalah pada laki-laki sebesar 3,6 dari 4,3 mg/dl menjadi 7,9 mg/dl dan perempuan 2,8 dari 4,8 mg/dl menjadi 7,6 mg/dl.Total jumlah subjek hiperurisemia pada akhir observasi sebanyak 9 subjek, terdiri dari 7 perempuan dan 2 laki-laki. Semua subjek tersebut diberikan pengobatan herbal untuk hiperurisemianya dan dianjurkan kembali kontrol setelah 2 minggu.

Tabel 4. Subyek dengan Kadar Asam Urat lebih dari Normal pada H-0 dan Perubahannya pada H-28

\begin{tabular}{llll}
\hline No Subyek & Jenis kelamin & Kadar Asam Urat (mg/d) & H-28 \\
\cline { 3 - 4 } & & $\mathrm{H}-0$ & 6,1 \\
\hline 1 & Laki-laki & 8,1 & 3,8 \\
2 & Perempuan & 6,2 & 6,4 \\
4 & Perempuan & 6,7 & 6,2 \\
5 & Perempuan & 7,2 & 5,9 \\
6 & Perempuan & 6,1 & 6,8 \\
\hline
\end{tabular}

Pada penelitian ini, hanya terjadi sedikit peningkatan rerata asam urat yang secara statistik tidak bermakna setelah pemberian jamu selama 28 hari. Bahkan pada 23 subjekkadar asam uratnya justru turun.Kandungan tempuyung yang terdapat dalam ramuan mampu menghambat enzim xantin oksidase sehingga berperan menurunkan kadar asam urat dalam darah[13]. Enam dari tujuh subjek yang sejak awal observasi telah menderita hiperurisemia juga mengalami penurunan kadar asam urat serum. Menurut Peluso et al ekstrak teh dapat meningkatkan kadar asam urat serum pada subjek normal dan menurunkannya pada subjek hiperurisemia[4,14]. Fenomena ini dapat berkaitan dengan dual efek dari polifenol yang terkandung dalam teh terhadap kadar asam urat. Polifenol dapat menurunkan produksi asam urat dan meningkatkan ekskresinya, tapi dapat pula mencegah terjadinya oksidasi asam urat karena asam urat merupakan salah satu antioksidan (4).

Ada beberapa variabel yang tidak bisa dikendalikan yang berperan dalam meningkatkan kadar asam urat selain faktor ramuan jamu dalam penelitian ini, yaitu genetik dan pola makan. Sayangnya, tidak ada data tentang riwayat hiperurisemia dalam keluarga maupun riwayat menderita hiperurisemia sebelumnya . Di samping itu, Tidak ada anjuran agar subyek menghindari makanan tinggi purin.

\section{Kesimpulan}

Pada akhir penelitian terjadi peningkatan ringan rerata kadar asam urat serum pasien yang secara statistik tidak bermakna dan masih berada dalam rentang nilai normal setelah pemberian ramuan jamu antihiperkolesterolemia selama 28 hari. Perlu dipertimbangkan adanya edukasi terutama bagi pasien yang memiliki riwayat/keturunan hiperurisemia untuk membatasi makanan dengan kandungan asam urat tinggi selama meminum ramuan jamu ini.

\section{Ucapan Terima Kasih}

Tim peneliti mengucapkan terima kasih kepada kepala B2P2TOOT beserta staf dan seluruh pegawai di RRJ Hortus medicus. Tak lupa kami ucapkan terima kasih kepada seluruh subjek penelitian yang tidak dapat kami sebutkan satu persatu.

\section{Daftar Pustaka}

[1] Pribadi E. Pasokan dan Permintaan Tanaman Obat Indonesia serta Arah Penelitian dan Pengembangannya. Perspektif. $2009 ; 8(1): 52-64$.

[2] Dewoto HR. Pengembangan Obat Tradisional Indonesia Menjadi Fitofarmaka *. Maj Kedokt Indones. 2007;57(7):205-11.

[3] Zulkarnain Z, Triyono A. Antihiperkolesterolemia Jamu Formula Effect on Plasma Cholesterol Levels in Patients with Mild Hypercholesterolemia in Rumah Riset Jamu "Hortus Medicus" Tawangmangu. Wahono Sumaryono, Shirly Kumala, Swasono R Tamat, Partomuan Simanjutak, Syamsudin YD, editor. Jakarta: Faculty of Pharmacy, Pancasila University; 2015. 211-217 p.

[4] Zhang Y, Cui Y, Li X, Li L, Xie X, Huang Y, et al. Is tea consumption associated with the serum uric acid level, hyperuricemia or the risk of gout? A systematic review and meta-analysis. BMC Musculoskelet Disord [Internet]. 2017;18(1):95. Available from: 
http://bmcmusculoskeletdisord.biomedcentral.com/articles/10.1186/s12891-017-1456-X

[5] Susilowati. Pengelolaan Terkini Pasien dengan Asam Urat. J AKP. 2012;3(1):16-8.

[6] Khosla UM, Zharikov S, Finch JL, Nakagawa T, Roncal C, Mu W, et al. Hyperuricemia induces endothelial dysfunction. Kidney Int. 2005;67(5):1739-42.

[7] Del Rio D, Stewart AJ, Mullen W, Burns J, Lean MEJ, Brighenti F, et al. HPLC-MS ${ }^{\mathrm{n}}$ Analysis of Phenolic Compounds and Purine Alkaloids in Green and Black Tea. J Agric Food Chem [Internet]. 2004;52(10):2807-15. Available from: http://pubs.acs.org/doi/abs/10.1021/jf0354848

[8] Sharma M, Chopra S, Prasad SB. Guazuma tomentosa: A valuable medicinal plant. Int J Pharmacogn Phytochem Res. 2015;7(1):197-200.

[9] Mayers V., Wardell E. The Influence of the Ingestion of Methyl Xanthines on The Excretion of Uric Acid.”. J Biol Chem. 1928;77(2):697722.

[10] Ashihara H, Sano H, Crozier A. Caffeine and related purine alkaloids: Biosynthesis, catabolism, function and genetic engineering. Phytochemistry. 2008;69(4):841-56.

[11] Das M, Borah NC, Ghose M, Choudhury N. Reference Ranges for Serum Uric Acid among Healthy Assamese People. Biochem Res Int. 2014;2014.

[12] WHO. Raised Cholesterol [Internet]. 2018. Available from: http://www.who.int/gho/ncd/risk_factors/cholesterol_text/en/

[13] Widyarini KD, Sukandar EY, Fidrianny I. Xanthine oxidase inhibitory and antihyperuricemic activities of anredera cordifolia (Ten) steenis, sonchus arvensis 1, and its combination. Int J Pharm Pharm Sci. 2015;7(3):86-90.

[14] Peluso I, Teichner A, Manafikhi H, Palmery M. Camellia sinensis in asymptomatic hyperuricemia: A meta-analysis of tea or tea extract effects on uric acid levels. Crit Rev Food Sci Nutr. 2017;57(2):391-8. 